\title{
Vol. 65, No. 44
}

In the report, "Incidence of Zika Virus Disease by Age and Sex - Puerto Rico, November 1, 2015-October 20, 2016," on page 1219 the following person should have been included as an author: Luisa I. Alvarado, MD, Ponce Health Sciences University-Saint Luke's Episcopal Hospital Consortium, Puerto Rico. 